\title{
Influencing Generations: Pre-service teachers' environmental worldviews at a South African university
}

Paul Goldschagg and Dianne Long, University of Witwatersrand, South Africa

\begin{abstract}
One of the key means of achieving environmental mindfulness is through education. Using a social transformation orientation lens and questions in the Revised New Ecological Paradigm (NEP) scale (Dunlap, Van Liere, Mertig \& Emmet Jones, 2000), this study at a South African university examines the environmental worldviews of a cohort of pre-service education students prior to and after completing an introductory module on Resources and Environmental Management as part of a Social Science course. Quantitative results indicate that the module did not change NEP scores significantly, suggesting that engagement with the course content is low and hence concern for the environment is low. The results suggest that more emphasis ought to be placed on environmental education to improve pre-service education students' mindfulness towards the environment.
\end{abstract}

Keywords: sustainability and environmental education in teacher education; Geography education; environmental worldviews

\section{Introduction}

Achieving environmental sustainability rose to prominence on the global agenda as far back as 1987 when the World Commission on Environment and Development released a report entitled Our Common Future (commonly known as the Brundtland Report), which essentially addressed concern for the environment and proposed long-term environmental strategies for achieving sustainable development (Brundtland, 1987). Since the adoption of sustainability as the overarching principle of environmental governance, scholars have not only debated what sustainability means, but also how to achieve sustainability (Holden, Linnerud \& Banister, 2017). One of the key means by which we, as a global citizenry, are to achieve sustainability is through education (Woodworth, Steen-Adams \& Mittal, 2011; Evans, et al., 2017). Through developing an understanding of the environment and our relationship with the environment, we can foster mindsets that promote sustainable actions at an individual level (UNESCO, 2021). This study seeks to examine the environmental worldviews of a first-year cohort of pre-service Bachelor of Education teaching students prior to and after completing a module on environmental resource management (one of four modules in a 'Geography in Education' level one course). The importance and necessity 
of this study is twofold. Firstly, it will examine the impact that this module had in changing students' mindsets. Secondly, the student participants are future educators who will go on to educate pupils in a school setting. The importance of understanding their worldviews, and whether these have changed (or not) is essential given the many generations they will in future influence through their teaching. The findings of this study will also help determine whether the course should be reimagined.

\section{Literature review}

A person's environmental worldview is an expression of the values that person associates with the environment and its resources (Evans, et al., 2017). Environmental worldviews can be said to lie on a continuum from biocentric, or nature-based, to anthropocentric, or human-based (Van Riper \& Kyle, 2014). Biocentric worldviews are formulated out of a high value being placed on the environment where concern for the environment goes beyond the concern for self (Nordlund \& Garvill, 2002; Wynveen, et al., 2021). On the other hand, anthropocentric worldviews represent values that consider the fulfilling of human needs to be the core function of the environment, which therefore exists for us to utilise and exploit to our benefit (Nordlund \& Garvill, 2002; Wynveen, et al., 2021).

Researchers have found links between the values held by a person concerning the environment, reflected in their worldview, and the resulting attitudes and behaviour towards the environment (Dietz, Fitzgerald, \& Shwom, 2005; Amos \& Carvalaho, 2020). People's actions are linked to where on the continuum of biocentric to anthropocentric worldviews they are located. Anthropocentric worldviews arguably cultivate the exploitation of the environment for human gain regardless of the sustainability of this exploitation. In order to change this worldview and foster environmentally responsible behaviour, it has been argued that society needs to improve environmental literacy, which in turn will shift people's beliefs or value systems as they relate to the environment (Woodworth, et al., 2011; Ling, et al., 2020).

Many universities have included some form of environmental education in their programmes in a bid to promote environmental literacy with the end goal of eliciting sustainable behaviour at a national and global level (Woodworth, et al., 2011; Reddy, 2021). Research on these programmes has found that simply by educating students on environmental issues, their environmental concern was raised and their worldviews shifted in line with their concern (Pe'er, Goldman \& Yavetz, 2007; Shephard, et al., 2009; Woodworth, et al., 2011; Reddy, 2021).

Several studies have been conducted looking into the environmental worldviews of students and staff across education sectors (Cotton et al., 2007; Liu \& Lin, 2014; Manoli, Johnson \& Dunlap, 2007; Pe'er, et al., 2007; Shumba \& Kampamba, 2013; Strack, et al., 2017). The Revised New Ecological Paradigm (NEP) (Dunlap, et al., 2000) has been used repeatedly in such studies with relative success. The NEP is a survey-based instrument comprising 15 statements and is designed to measure the environmental concerns and values of people. (Dunlap, 2008; Van Riper \& Kyle 2014). By assessing participant responses to statements 
that are designed to bring to light the participants' environmental values, their worldviews can be understood on the continuum between biocentric and anthropocentric.

The desire to influence students' worldviews towards more sustainable value systems is seen as a positive outcome of teaching students environmental education at a tertiary level (Shephard, et al., 2009; Brennan, 2017). This ideal drives institutional mandates for environmental education: "educators must take the lead in sustainability so that our graduates can be encouraged and supported to promote sustainable practices in their chosen career" (Shephard, et al. 2009, p. 572; Brennan (2017). Furthermore, it is noted that teaching students about environmental concerns in a bid to foster a biocentric worldview is important, as it is these students who are our future leaders (Kopnina, 2019). Therefore, teaching environmental sustainability for the purposes of changing future leaders' values and behaviour is fitting at the tertiary level.

This is possibly even more justifiable when it is future teachers being educated. It is these educators who could also promote sustainable practices in their forthcoming careers (Shephard, et al., 2009; Evans, et al., 2017). Despite the importance of educating pre-service teachers to ensure they incorporate sustainability teaching in their future careers, studies have shown that teachers have been poorly trained for this (Pe'er, et al., 2007; Reddy, 2021). The extent to which sustainability education has been integrated into initial teacher education curricula is unclear (Evans, et al., 2017) or requires substantial revision (Brennan \& Widdop Quinton, 2020). This is problematic if one is to assume that the "adequate preparation of teacher education students in environmental education is a prerequisite for their future ability to design and implement effective environmental education" (Pe'er, et al., 2007, p. 393).

This study seeks to understand if student teachers' environmental worldviews change after completing a module on Resources and Environmental Management.

The Resources and Environmental Management module emphasises human impact on the environment while exposing students to different theoretical approaches to managing the Earth's resources. These approaches included Free Market Environmentalism, Sustainable Development, Conservation and Environmental Justice. The module, along with the assessments therein, was designed to get students to critically reflect on human impacts on the environment and the various theoretical approaches, which can be used to manage or reduce these impacts. Students were encouraged to form an opinion and argue for whichever theory they believed to be the most appropriate for managing South Africa's natural resources.

The aim here is to see whether student teachers exit the course with a more biocentric worldview. Subsequently, the study wishes to see whether a change in worldview also changes the way in which students will teach environmental subjects in future to their own pupils. This will allow us to consider whether there is a lasting change encouraged through environmental education at a tertiary level to student teachers. 


\section{Methodology}

This study used purposive sampling (Patton, 2002) in an exploratory research design (Stebbins, 2001), whereby an inductive approach (Thomas, 2006) was taken to gain new insights into the extent to which the module influenced environmental worldviews. A mixed methods approach (Denscombe, 2008) was used to gather both qualitative data and quantitative data. For the quantitative data, questions from the Revised New Ecological Paradigm scale (Appendix 1) were administered before and after the module. For the qualitative data, at the conclusion of the module, students were invited to respond to five open-ended questions (Appendix 2) which sought to give them an opportunity to express their opinions freely, having completed the module.

The survey was undertaken at a School of Education in a South African university among students registered for an elective Social Sciences first-year module (six weeks in duration) entitled Resources and Environmental Management, as part of a four-year Bachelor of Education degree. All students registered for the class were eligible and were invited to participate in the survey, which was administered before the commencement and at the conclusion of the module. Since the authors wanted to see whether their input in the module had an impact, Glaser and Strauss's Grounded Theory (1967) was followed, approaching the research with an open mind "to discovering new factors of relevance to an explanation of that area" (Denscombe, 1998, p. 215). In this sense, the authors elected to follow a trail of discovery to see what impact the module had, and later to determine what paths could be followed in future to improve outcomes.

The revised New Ecological Paradigm (NEP) Scale is a widely used measure of environmental orientation, and was developed by Dunlap, Van Liere, Mertig and Emmet Jones (2002), based on the original work of Dunlap and Van Liere in 1978. Containing fifteen statements, it investigates a range of environmental worldviews, assessing proand anti-sentiments using a five-point Likert scale (Appendix 1). Response items on the Revised NEP are phrased so that the pro- environmental responses are alternated between agreeing and disagreeing.

The survey was administered to all registered Social Science 1 students who were present in class. Using a pre- (BEFORE) and post-course (AFTER) intervention study design, the surveys were administered on the first and last days of the course. A total of 295 students participated in the course. The response rates, and proportion of qualifying responses, are presented in Table 1. 
Table 1: Response rates and qualifying responses

\begin{tabular}{|l|c|c|c|c|}
\cline { 2 - 5 } \multicolumn{1}{c}{} & \multicolumn{2}{c|}{ Before } & \multicolumn{2}{c|}{ After } \\
\cline { 2 - 5 } \multicolumn{1}{c|}{} & $\mathbf{n}$ & $\%$ & $\mathbf{n}$ \\
\hline Number of students in course & 295 & & 295 & 36.9 \\
\hline All respondents & 146 & 49.5 & 109 & 32.2 \\
\hline Completed both questionnaires & 95 & 32.2 & 95 & 34.6 \\
\hline Qualifying respondents & 131 & 44.4 & 102 & 27.8 \\
\hline Completed both questionnaires & 82 & 27.8 & 82 & 6.8 \\
\hline Completed only first questionnaire & 49 & 16.6 & 20 & \\
\hline
\end{tabular}

The overall response rate for BEFORE and AFTER was $49.5 \%$ and $36.9 \%$. Only $32.2 \%$ of the students completed both questionnaires. Fifteen and seven students in BEFORE and AFTER, respectively, did not complete all 15 items of the NEP and were not considered in further analysis. This leaves 82 qualifying students (27.8\%) who completed both questionnaires and 49 and 20 who completed BEFORE only and AFTER only respectively. The relatively low participation in completing both questionnaires may say something about student's belief systems and engagement with the course content, more about which will be discussed in the conclusion.

The reliability of the NEP scale was determined by Cronbach alpha (Cronbach, 1951) and item-total correlations (Henrysson, 1963). Cronbach alpha values were low at 0.56 and 0.59 for BEFORE and AFTER respectively. (We look at the individual question scores later, to explore the reasons for the low values.) Comparison of the NEP score between BEFORE and AFTER using all respondents was carried out using the independent samples t-test at a $5 \%$ significance level. The mean increase in score from PRE to POST was 0.23 (95\% CI: 0.14$0.32)$; although this was statistically significantly greater than $0(\mathrm{p}<0.0001)$, the practical significance of such a small increase is likely to be small.

In addition to the NEP instrument, at the same time of completion of the instrument, students were asked a number of closed and open-ended questions in the second round of data collection - see Appendix 2). These questions were designed to look into why students have changed their worldviews, if these had changed, and how this will influence their future teaching, if at all. The responses to the open-ended questions were inductively coded independently by the two authors to increase the validity of the themes that emerged (Patton, 2002). 


\section{Results}

\section{Quantitative analysis}

When looking at the mean NEP scores both before and after the course, there was a clear indication of pro-NEP sentiment, or ecocentric worldview, amongst the students in the course. The mean NEP scores in all cases were $>3$, indicating pro-NEP sentiment. This means that the overall sentiment of the students towards environmental conservation and sustainability was positive before and after the course. The mean increase in score from before the course to after the course was $6.3 \%$. This $6.3 \%$, when looked at as an overall NEP score, masks the individual changes in each question response. Table 2 summarises the percentage changes before and after the course.

Table 2: Summary of the NEP scores

\begin{tabular}{|c|c|c|c|c|c|c|c|c|c|c|}
\hline & $\frac{0}{\frac{0}{0}}$ & 离 & $\begin{array}{l}0 \\
\frac{0}{0} \\
\infty \\
\infty\end{array}$ & 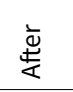 & $\begin{array}{l}0 \\
\frac{0}{0} \\
\infty \\
\infty\end{array}$ & 离 & $\begin{array}{l}\frac{0}{0} \\
\frac{0}{\nu} \\
\infty\end{array}$ & 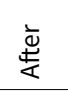 & $\begin{array}{l}\frac{0}{0} \\
\frac{0}{2} \\
\infty\end{array}$ & $\begin{array}{l}\bar{\Phi} \\
\stackrel{+}{\alpha}\end{array}$ \\
\hline Statement & 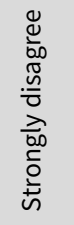 & 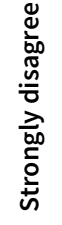 & 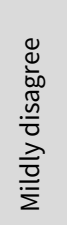 & 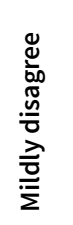 & $\begin{array}{l}\stackrel{0}{\bar{y}} \\
\stackrel{5}{5}\end{array}$ & $\begin{array}{l}\stackrel{0}{5} \\
\text { ज̆ } \\
\stackrel{5}{5}\end{array}$ & 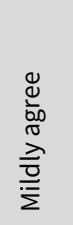 & 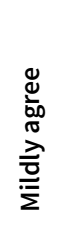 & 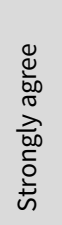 & 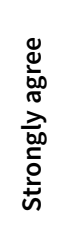 \\
\hline $\begin{array}{l}\text { 1. We are approaching the } \\
\text { limit of the number of } \\
\text { people the Earth can } \\
\text { support }\end{array}$ & 11.5 & 4.9 & 4.6 & 2.0 & 5.3 & 5.9 & 37.4 & 24.5 & 41.2 & 62.8 \\
\hline $\begin{array}{l}\text { 2. Humans have the right } \\
\text { to modify the natural } \\
\text { environment to suit their } \\
\text { needs }\end{array}$ & 16.8 & 28.4 & 24.4 & 26.5 & 15.3 & 13.7 & 29.8 & 21.6 & 13.7 & 9.8 \\
\hline $\begin{array}{l}\text { 3. When humans interfere } \\
\text { with nature it often } \\
\text { produces disastrous } \\
\text { consequences }\end{array}$ & 3.8 & 4.9 & 3.8 & 0.0 & 12.2 & 5.9 & 26.7 & 18.6 & 53.4 & 70.6 \\
\hline $\begin{array}{l}\text { 4. Human ingenuity will } \\
\text { ensure that we do NOT } \\
\text { make the Earth unliveable }\end{array}$ & 9.16 & 13.7 & 6.9 & 10.8 & 47.3 & 32.4 & 21.4 & 27.5 & 15.3 & 15.7 \\
\hline $\begin{array}{l}\text { 5. Humans are severely } \\
\text { abusing the environment }\end{array}$ & 2.3 & 4.9 & 4.6 & 0.0 & 2.3 & 2.0 & 29.0 & 26.5 & 61.8 & 66.7 \\
\hline $\begin{array}{l}\text { 6. The Earth has plenty of } \\
\text { natural resources if we } \\
\text { just learn how to develop } \\
\text { them }\end{array}$ & 5.3 & 4.9 & 6.1 & 8.8 & 6.9 & 7.8 & 23.7 & 21.6 & 58.0 & 56.9 \\
\hline
\end{tabular}




\begin{tabular}{|c|c|c|c|c|c|c|c|c|c|c|}
\hline & $\frac{\substack{0 \\
\frac{0}{0}}}{\infty}$ & 离 & $\begin{array}{l}\mathscr{0} \\
\frac{0}{\Phi} \\
\infty\end{array}$ & 离 & $\frac{0}{0}$ & 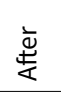 & $\frac{\mathscr{0}}{\stackrel{0}{\nu}}$ & 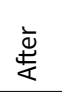 & $\frac{\substack{0 \\
\frac{0}{2}}}{\infty}$ & $\underset{\frac{\Phi}{\alpha}}{\stackrel{\Phi}{\alpha}}$ \\
\hline Statement & 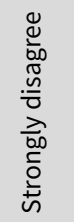 & 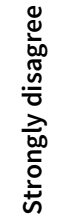 & 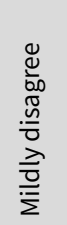 & 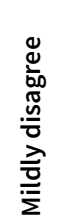 & 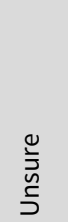 & 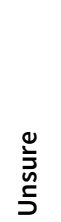 & $\begin{array}{l}\frac{\Phi}{\Phi} \\
\text { कू } \\
\frac{\pi}{2} \\
\stackrel{\overline{0}}{\bar{\Sigma}}\end{array}$ & 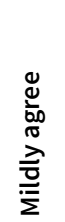 & 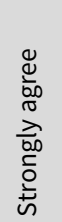 & 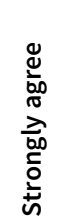 \\
\hline $\begin{array}{l}\text { 7. Plants and animals have } \\
\text { as much right as humans } \\
\text { to exist }\end{array}$ & 0.76 & 0.0 & 1.53 & 1.0 & 3.8 & 1.0 & 12.2 & 9.8 & 81.7 & 88.2 \\
\hline $\begin{array}{l}\text { 8. The balance of nature is } \\
\text { strong enough to cope } \\
\text { with the impacts of } \\
\text { modern industrial nations }\end{array}$ & 38.9 & 54.9 & 33.6 & 21.6 & 16.0 & 12.8 & 7.6 & 6.9 & 3.8 & 3.9 \\
\hline $\begin{array}{l}\text { 9. Despite our special } \\
\text { abilities, humans are still } \\
\text { subject to the laws of } \\
\text { nature }\end{array}$ & 5.3 & 2.0 & 6.9 & 3.9 & 19.9 & 29.4 & 30.5 & 29.4 & 37.4 & 35.3 \\
\hline $\begin{array}{l}\text { 10. The so-called "ecological } \\
\text { crisis" facing humankind } \\
\text { has been greatly } \\
\text { exaggerated }\end{array}$ & 42.7 & 52.9 & 19.1 & 21.6 & 26.0 & 18.6 & 9.2 & 3.9 & 3.1 & 2.9 \\
\hline $\begin{array}{l}\text { 11. The Earth is like a } \\
\text { spaceship with very } \\
\text { limited room and } \\
\text { resources }\end{array}$ & 12.2 & 4.9 & 14.5 & 9.8 & 9.2 & 4.9 & 33.6 & 31.4 & 30.5 & 49.0 \\
\hline $\begin{array}{l}\text { 12. Humans were meant } \\
\text { to rule over the rest of } \\
\text { nature }\end{array}$ & 44.3 & 51.0 & 14.5 & 12.8 & 12.2 & 9.8 & 13.0 & 12.8 & 16.0 & 13.7 \\
\hline $\begin{array}{l}\text { 13. The balance of nature is } \\
\text { very delicate and easily } \\
\text { upset }\end{array}$ & 5.3 & 0.0 & 7.6 & 3.9 & 19.9 & 12.8 & 29.8 & 33.3 & 37.4 & 50.0 \\
\hline $\begin{array}{l}\text { 14. Humans will eventually } \\
\text { learn enough about how } \\
\text { nature works to be able } \\
\text { to control it }\end{array}$ & 7.6 & 13.7 & 22.9 & 13.7 & 20.6 & 31.4 & 29.8 & 30.4 & 19.1 & 10.8 \\
\hline $\begin{array}{l}\text { 15. If things continue on their } \\
\text { present course, we will } \\
\text { soon experience a major } \\
\text { ecological catastrophe }\end{array}$ & 2.3 & 1.0 & 0.76 & 2.0 & 6.9 & 1.0 & 16.0 & 16.7 & 74.0 & 79.4 \\
\hline
\end{tabular}


It can be observed from Table 2 that responses to certain questions change rather substantially before and after the course. These changing responses are further explored below. In item 1 , there was a significant increase of $21.58 \%$ of students who strongly agreed that we are approaching the limit of the number of people the Earth can support. The module was therefore successful in making students aware of the limited capacity of the Earth to support the human population.

Item 3 shows that $70.6 \%$ of students, having completed the module, now believe that human interference with nature often produces disastrous consequences when compared with the response before, of 53.4\% (which was already a reasonable level of environmental awareness). This is still a substantial increase of $17.2 \%$ from the start of the course. Another instance of a change in the students' NEP scores worth mentioning relates to item 4 . There was a $14.9 \%$ decrease in the number of students who are now unsure that human ingenuity will not make the Earth unliveable. These students are now tending to disagree more strongly with the statement, which is a positive finding, indicating that on completion of the module, more students are now of the view that human ingenuity will ensure a sustainable viable Earth.

For item 8, "The balance of nature is strong enough to cope with the impacts of modern industrial nations", after completion of the module there are more students who have shifted from mildly disagreeing to strongly disagreeing. There was, however, little change in the mean score of the students who agreed, before and after. This illustrates that a beforecourse belief in the negative impacts of industrial development was strengthened during the module, and can be linked to the module on the environmental impact of mining on water quality.

Of note is the change in responses before and after the course for item 11 . After attending the module, students now believe more strongly that the Earth is like a spaceship with limited room and resources. This increase is relative to a decrease in the number of students who previously disagreed with this statement. The change in item 11 is mirrored in item 13 where more students now strongly agree that the balance of nature is very delicate and easily upset. Therefore, we can see that students now appreciate that the Earth's resources are limited and easily disturbed, in line with the ecocentric view.

An interesting change is evident for item 14. Before the module, more students both agreed and disagreed with the statement that "humans will eventually learn enough about how nature works to be able to control it". These students now make up the majority of participants who are, on completion of the module, "unsure" of their response to this statement. The course almost certainly made them more aware of the complexity of the issues, whilst the lecturers realised that content needs fine-tuning to help students develop deeper insights.

In relation to item 15, "if things continue on their present course, we will soon experience a major ecological catastrophe", at the conclusion of the course, the number of unsure students decreased from $2.3 \%$ to $1 \%$ in relation to item 15 , whilst the number of 
students who strongly agreed went up to $79.4 \%$ from $74.05 \%$. Overall, this does tie in with students realising that things cannot simply continue as they have in the past.

\section{Qualitative analysis}

All 295 students were also invited to respond to five questions (developed by the authors, see Appendix 2) as part of the survey at the course's conclusion, to explore the reasons behind any change that had occurred, and how this may influence their future teaching. Analysis of the qualitative data suggests that the module developed a more nuanced understanding of the environmental issues dealt with. In a close-ended question, students were asked whether they felt that their level of environmental concern had changed after taking the Resources and Environmental Management module. Of the 112 responses to this question, 111 students believe that their level of concern has changed. For the one student whose environmental concern had not changed, his/her reasoning was that "It hasn't changed because I did not get more information about managing the resources". For this student, who was already environmentally aware at the start of the module, the module did little to inform or change his/her opinion. For the remaining 111 responses indicating a change, the responses were coded using thematic content analysis (Given, 2008) and five main themes emerged. Coding showed that student responses could have multiple themes embedded within them and therefore the number of instances a theme occurred does not total to the number of students who responded to the question. The themes identified are presented in Table 3.

Table 3: Themes which emerged from thematic content analysis

\begin{tabular}{|l|l|}
\hline Theme & $\begin{array}{l}\text { Number of students who } \\
\text { identified the theme as a reason } \\
\text { for their change in concern }\end{array}$ \\
\hline $\begin{array}{l}\text { 1. Human actions degrading the environment, and inadequate } \\
\text { environmental management. }\end{array}$ & 41 \\
\hline 2. Concern regarding the scarcity of resources & 11 \\
\hline 3. Concern for future generations & 14 \\
\hline $\begin{array}{l}\text { 4. Students' thinking changed due to becoming more aware of the } \\
\text { environmental impacts associated with human beings }\end{array}$ & 67 \\
\hline $\begin{array}{l}\text { 5. The negative impacts of environmental exploitation on } \\
\text { communities living in that environment }\end{array}$ & 16 \\
\hline
\end{tabular}

In a follow-up question (Question 2, Appendix 2), students were asked whether this change was indicative of an increase or decrease in their concern. It is noteworthy that all 112 respondents indicated an increased level of concern. When coding their open-ended responses as to why their concern has increased or decreased, four themes emerged (see Table 4). 
Table 4: Themes which emerged from responses regarding levels of concern

\begin{tabular}{|l|c|}
\hline Theme & $\begin{array}{l}\text { Number of students who } \\
\text { identified the theme as a reason } \\
\text { for their change in concern }\end{array}$ \\
\hline 1. An awareness of increasing environmental degradation & 22 \\
\hline 2. Increased awareness of the state of the environment overall & 45 \\
\hline 3. Concern for impacts on current and future generations & 46 \\
\hline $\begin{array}{l}\text { 4. An awakening of environmental conscience and increased } \\
\text { understanding of own contribution to degradation }\end{array}$ & 46 \\
\hline
\end{tabular}

The qualitative responses garnered through the study are rich and illustrate the mounting concern students now feel concerning the environment. Student X noted that his/her concern "has increased because I have become aware of the activities which threaten the environment. I have also done a self-introspection to check how badly I contribute to the destruction of the environment". The course has therefore not only enabled students to be critical of environmental management practices on a broader scale, but has also made them reflective on a personal level. This personal reflection led to strong emotions of attachment to the environment: "The environment has become so important to me that I have integrated it into my daily routine, I feel more responsible to look after the environment and I want to be a part of the change to make for a better place" (Student XX). A sense of empathy has also been elicited in some students as is illustrated in this quote from Student XXX: "As much as I am not directly affected by the negative consequences, I am now fully aware of the issues faced by many of my fellow brothers and sisters out there and also the struggles they face in trying to fight for their health, due to the diseases they suffer from".

The final closed-ended question required students to reflect on whether the course had enabled them to clarify their worldviews. Of the 112 respondents to the question, 97 said 'yes', three said 'no' whilst there were 12 non-responses. The non-responses could be attributed to students who did not turn the survey sheet over and therefore did not see the last questions.

For one of the students unable to clarify his/her worldview, the reasoning was as follows: "The course readings mainly stated the problems around the environment, not the solutions." This response suggests that students require knowledge of the solutions before they are willing to clarify their own personal worldview. However, this does not reflect the nature of the contested environment and how it should be managed. For another student, confusion stems from the inability to align themselves with any one of the various theories presented to them on environmental management. Their response also illustrates concerns around sustainable development as an approach which seeks to mutually promote the good of the environment, the economy and society rather than seeing these three as being in conflict: "I am still not sure whether we should put the environment before humans or work more toward sustainable development". 
Students were asked (Question 4, Appendix 2) in what ways they were likely to change their environmental behavior as a result of knowing their worldviews. The 129 responses received are summarised in Table 5 .

Table 5: Ways students report they are likely to change their environmental behaviour as a result of doing the module

\begin{tabular}{|l|l|}
\hline Theme & $\begin{array}{l}\text { Number of students who } \\
\text { identified the theme as a reason } \\
\text { for their change in behaviour }\end{array}$ \\
\hline $\begin{array}{l}\text { 1. Reduce resource consumption (examples given include: water, } \\
\text { electricity, car usage) }\end{array}$ & 49 \\
\hline $\begin{array}{l}\text { 2. Response indicates an awareness without any action identified } \\
\text { 3. Student will engage in proper waste management i.e. no longer } \\
\text { littering }\end{array}$ & 20 \\
\hline $\begin{array}{l}\text { 4. Promotion of environmental citizenship, example: reporting } \\
\text { water leaks and joining protests. }\end{array}$ & 33 \\
\hline
\end{tabular}

\section{Discussion}

The aim of the Resources and Environmental Management module in the Geography in Education course was to give students a better understanding of human impacts on the environment and to encourage them to form an opinion regarding environmental management. In the process, four theoretical approaches to managing the environment were presented; not all of these theories promoted an ecocentric worldview regarding the way the environment should be managed. Proponents of the theory of free market environmentalism, for instance, advocate that human ingenuity will enable humans to innovate their way out of environmental crises and thus takes an anthropocentric stance on environmental decision making and management (Martin, Maris \& Simberloff, 2016). Conservation as a theory, on the other hand, promotes a biocentric approach, where all life, including that of fauna and flora, is to be preserved for its intrinsic value and not necessarily for the usefulness of species to humans.

What we are able to see from the NEP scores, which measure pro-environmental worldviews as those that are aligned with a biocentric outlook, is that students both before and after the module did not align themselves with a biocentric management approach such as conservation, as much as they did with the anthropocentric approach of free market environmentalism. This is evident when statements two and four are considered: as a result of attending the module, students seem to have shifted their worldviews towards being more pro-human ingenuity and humanity's ability to manage the environment.

The results of the NEP survey indicate that in addition to the module not making a meaningful difference in changing student's NEP scores, it did not help students to clarify their worldviews. Despite having completed the course, many students are unsure of 
their opinion with regard to NEP statements. For some questions, the number of 'unsure' students increased, for example items 4 and 14. This suggests that a longer or more focused course is needed to help with clarity; however, it is unlikely that a longer course will have much impact in changing students' associated worldviews from anthropocentric to biocentric. In an age where human ingenuity is at the forefront of progress it seems likely that students will more readily align themselves with theories that propose to manage the environment in this way.

While we cannot say that the course had the intended impact in changing student's NEP scores, we can say that students are, as a result of the module, more engaged with environmental concerns now than they were before and would change their behaviour. The multi-generational impact of the module can be significant if students implement changes in practices as teachers.

When looking at both the quantitative NEP data and the qualitative responses, we can argue that while the NEP survey does not indicate significant pro-environmental change in students' worldviews, it also does not capture the depth of impact of the module on the students. It is possible that these students, while finding themselves more aligned with an anthropocentric theory of managing the environment, have still been positively impacted by the module. Future longitudinal research to assess the long-term impact of short course modules is necessary.

\section{Conclusion}

In this research, our aim was to understand whether a short course (module) on the environment brought about a change in environmental worldviews. The current practice in the university where the study was undertaken, as in other higher education institutions, is to bring environmental education into a course as one of the curriculum modules with the expectation that it will foster lasting change among the students. However, based on the findings of this study we would argue that a module is not necessarily enough to take students from uncertainty to certainty in their understanding. Furthermore, a module cannot be certain to change a worldview to a biocentric one as reflected in a high NEP score, if it is to be a critical appraisal of all the options on environmental management, rather than a narrow promotion of only one option, which would limit students from making an informed decision for themselves.

Ongoing research in local contexts is needed to identify the factors that influence positive environmental worldviews and this would be the next logical step in this research.

In the words of Kioupi and Voulvoulis (2019, p. 1), our understanding of sustainability problems "is incomplete and in part clouded by profound uncertainties" and perhaps the best that can be expected from an introductory module is for students to see the bigger picture and understand the transformative role education can play in transitioning to sustainability. The next steps in future research are to investigate what recommendations can be made to Education faculties to ensure that students engage with environmental concerns, and work out how to teach effectively about these. 


\section{Appendices}

\section{Appendix 1: Revised New Ecological Paradigm Statements (Dunlap, 2000)}

How strongly do you agree or disagree with each of these statements?

Tick the appropriate box that matches your feelings towards the statement.

\begin{tabular}{|c|c|c|c|c|}
\hline 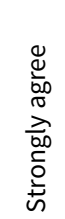 & 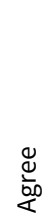 & 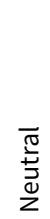 & 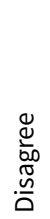 & 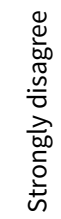 \\
\hline
\end{tabular}

1. We are approaching the limit of the number of people the Earth can support

2. Humans have the right to modify the natural environment to suit their needs

3. When humans interfere with nature it often produces disastrous consequences

4. Human ingenuity will ensure that we do NOT make the Earth unliveable

5. Humans are severely abusing the environment

6. The Earth has plenty of natural resources if we just learn how to develop them

7. Plants and animals have as much right as humans to exist

8. The balance of nature is strong enough to cope with the impacts of modern industrial nations

9. Despite our special abilities, humans are still subject to the laws of nature

10. The so-called "ecological crisis" facing humankind has been greatly exaggerated

11. The Earth is like a spaceship with very limited room and resources

12. Humans were meant to rule over the rest of nature

13. The balance of nature is very delicate and easily upset

14. Humans will eventually learn enough about how nature works to be able to control it

15. If things continue on their present course, we will soon experience a major ecological catastrophe 


\section{Appendix 2: Closed and open-ended questions}

Question 1: Has your level of environmental concern changed after taking this course?

Question 2: Do you think your concern over the environment has increased or decreased?

Question 3: How has this course enabled you to clarify your environmental worldview?

Question 4: In what ways are you likely to change your ecological behaviour as a result of knowing your worldview?

Question 5: As a result of knowing your worldview, how will your classroom teaching practice change? 


\section{Notes on Contributors and their Contributions}

\section{Lead author}

Goldschagg, Paul

Dr Goldschagg is a senior lecturer at the Wits School of Education where his scholarship is located within the broad theme of Geography, Sustainability and Environmental Education.

\section{Co-author}

Long, Dianne

Dr Long is a researcher focused on Geography and environmental studies at the Wits School of Education.

\section{Percentage contribution}

\begin{tabular}{|l|l|c|}
\hline \multirow{2}{*}{ Areas of contribution } & Author & $\begin{array}{c}\text { Percentage } \\
\text { contribution }\end{array}$ \\
\hline \multirow{2}{*}{ Conception or design of the paper, theory or key argument } & Goldschagg & $50 \%$ \\
\cline { 2 - 3 } & Long & $50 \%$ \\
\hline \multirow{2}{*}{ Data collection } & Goldschagg & $20 \%$ \\
\cline { 2 - 3 } & Long & $80 \%$ \\
\hline \multirow{2}{*}{ Analysis and interpretation } & Goldschagg & $80 \%$ \\
\cline { 2 - 3 } & Long & $20 \%$ \\
\hline \multirow{2}{*}{ Drafting the paper } & Goldschagg & $80 \%$ \\
\cline { 2 - 3 } & Long & $20 \%$ \\
\hline \multirow{2}{*}{ Critical review of paper } & Goldschagg & $90 \%$ \\
\cline { 2 - 3 } & Long & $10 \%$ \\
\hline
\end{tabular}




\section{References}

Amos, R. \& Carvalho, P. (2020). Locating a course on environmental justice in theories of environmental education and global citizenship. Journal of Education for Sustainable Development, 14(2), 140-155. doi:10.1177/0973408220980867.

Brennan, M. (2017). Struggles for teacher education in the age of the Anthropocene. Journal of Education, 69, 43-63.

Brennan, M. \& Widdop Quinton, H. (2020). An ethical re-framing of curriculum for sustainability education. Curriculum Perspectives 40, 105-110.

Brundtland, G. (1987). Report of the World Commission on Environment and Development: Our Common Future. United Nations General Assembly document A/42/427.

Cotton, D.R.E., Warren, M.F., Maiboroda, O. \& Bailey, I. (2007). Sustainable development, higher education and pedagogy: A study of lecturers' beliefs and attitudes. Environmental Education Research, 13(5), 579-597. doi: 10.1080/13504620701659061.

Cronbach, L.J. (1951). Coefficient alpha and the internal structure of tests. Psychometrika, 16(3), 297-334. doi:10.1007/bf02310555.

Denscombe, M. (1998). The Good Research Guide: For small-scale research projects. Buckingham: Open University Press.

Denscombe, M. (2008). Communities of Practice: A research paradigm for the mixed methods approach. Journal of Mixed Methods Research, 2(3), 270-283.

Dietz, T., Fitzgerald, A. \& Shwom, R. (2005). Environmental values Annual Review of Environment and Resources, 30(1), 335-372 doi:10.1146/annurev. energy.30.050504.144444.

Dunlap, R.E., Van Liere, K.D., Mertig, A.G. \& Jones, R.E. (2000). Measuring endorsement of the new ecological paradigm: A revised NEP scale, Journal of Social Issues, 56(3), 425-442.

Dunlap, R.E. (2008) The New Environmental Paradigm Scale: From marginality to worldwide use. Journal of Environmental Education, 40(1), 3-18.

Evans, N., Stevenson, R., Lasen, M., Ferreira, J. \& Davis, J. (2017).

Approaches to embedding sustainability in teacher education: A synthesis of the literature. Teaching and Teacher Education, 63, 405-417.

Given, E.D. (Ed.) (2008). The Sage Encyclopedia of Qualitative Research Methods. Thousand Oaks, California: Sage.

Glaser, B.G. \& Strauss, A.L. (1967). The Discovery of Grounded Theory: Strategies for qualitative research. Mill Valley, CA: Sociology Press.

Henrysson, S. (1963). Correction of item-total correlations in item analysis. Psychometrika, 28(2), 211-218. doi:10.1007/BF02289618.

Holden, E., Linnerud, K. \& Banister, D. (2017). The Imperatives of sustainable development. Sustainable Development, 25 (3): 213-226. doi: 10.1002/sd.1647.

Kioupi, V. \& Voulvoulis, N. (2019). Education for Sustainable Development: A systemic framework for connecting the SDGs to educational outcomes. Sustainability, 11, 1-18. doi:10.3390/su11216104. 
Kopnina, H. (2019). Ecocentric education: Student reflections on anthropocentrismecocentrism continuum and justice. Journal of Education for Sustainable Development, 13(1) 5-23.

Ling, S., Landon, A., Tarrant, M., \& Rubin D. (2020) Sustainability education and environmental worldviews: Shifting a paradigm. Sustainability, 12(8258). doi: 10.3390/su12198258.

Liu, S-C. \& Lin, H-S. (2014). Undergraduate students' ideas about nature and human-nature relationships: An empirical analysis of environmental worldviews. Environmental Education Research, 20(3), 412-429. doi:10.1080/13504622.2013.816266.

Manoli, C., Johnson, B., \& Dunlap, R. (2007). Assessing children's environmental worldviews: Modifying and validating the new ecological paradigm scale for use with children. Journal of Environmental Education, 38(4), 3-13. doi:10.3200/JOEE.38.4.3-13.

Martin J., Maris, V. \& Simberloff D.S. (2016). The need to respect nature and its limits challenges society and conservation science. Procedures of the National Academy of Sciences of the United States of America, 113(22), 6105-6112

Nordlund, A. \& Garvill, G. (2002). Value structures behind pro-environmental behavior. Environment and Behavior, 34(6), 740-56. https://doi.org/10.1177/001391602237244.

Patton, M. Q. (2002). Qualitative Research and Evaluation Methods (3rd ed.). Thousand Oaks, CA: Sage.

Pe'er, S., Goldman, D. \& Yavetz, B. (2007). Environmental literacy in teacher training: attitudes, knowledge, and environmental behavior of beginning students. Journal of Environmental Education, 39(1), 45-59. doi:10.3200/JOEE.39.1.45-59.

Reddy, C. (2021). Environmental education, social justice and teacher education: enabling meaningful environmental learning in local contexts. South African Journal of Higher Education, 35(1), 161-177. doi:10.20853/35-1-4427.

Shephard, K., Mann, S., Smith, N. \& Deaker, L. (2009). Benchmarking the environmental values and attitudes of students in New Zealand's post-compulsory education. Environmental Education Research, 15(5), 571-587. doi:10.1080/13504620903050523.

Shumba, O. \& Kampamba, R. (2013) Mainstreaming ESD into Science teacher education courses: A case for ESD pedagogical content knowledge and learning as connection. Southern African Journal of Environmental Education, 29, 151-166.

Stebbins, R. (2001). Exploratory research in the social sciences: Thousand Oaks: Sage.

Strack, M., Shephard, K., Jowett, T. Mogford, S. Skeaff, S. \& Mirosa, M. (2017). Monitoring surveying students' environmental attitudes as they experience higher education in New Zealand. Survey Review, November, 1-8. doi:10.1080/00396265.2017.1399526.

Thomas, D.R. (2006). A general inductive approach for analyzing qualitative evaluation data. American Journal of Evaluation, 27(2), 237-246.

UNESCO. (2021). What is Education for Sustainable Development? UNESCO https://en.unesco.org/themes/education-sustainable-development/what-is-esd 
Van Riper, C. \& Kyle, G. (2014). Capturing multiple values of ecosystem services shaped by environmental worldviews: A spatial analysis. Journal of Environmental Management, 145 (December), 374-384. doi:10.1016/j.jenvman.2014.06.014.

Woodworth, B., Steen-Adams, M. \& Mittal, P. (2011). Role of an environmental studies course on the formation of environmental worldviews: A case study of a core curriculum requirement using the NEP Scale. Journal of Environmental Studies and Sciences, 1(2), 126-137. doi:10.1007/s13412-011-0013-4.

Wynveen, C., Woosnam, K., Keith, S. \& Barr, J. (2021). Support for wilderness preservation: An investigation of the roles of place attachment and environmental worldview. Journal of Outdoor Recreation and Tourism, 35, 1-9. 